\title{
Earnings Management Prior to Initial Public Offerings and Its Effect on Firm Performance: International Evidence
}

\author{
Arjan Premti ${ }^{1}$ \\ ${ }^{1}$ Department of Finance, Florida Atlantic University, FL, USA \\ Correspondence: Arjan Premti, Department of Finance, Florida Atlantic University, FL, USA. E-mail: \\ apremti@fau.edu
}

Received: April 23, 2013

Accepted: May 28, 2013

Online Published: June 24, 2013

doi:10.5430/ijfr.v4n3p10

URL: http://dx.doi.org/10.5430/ijfr.v4n3p10

\begin{abstract}
This paper investigates the degree of discretionary current accruals $\left(\mathrm{DCA}_{-1}\right)$ prior to the initial public offerings (IPOs) of foreign firms in an attempt to study the two seemingly opposing views of Teoh, Welch, and Wong (1998) and Ball and Shivakumar (2008) in regards to pre-IPO earnings management. By analyzing a sample of 4962 IPOs from 28 countries, I find that, on average, IPO firms do not report significantly positive DCA $\mathrm{A}_{-1}$. This result supports the view held by Ball and Shivakumar that IPO firms do not engage in earnings management and it is inconsistent with the earnings management hypothesis of Teoh et al. (1998). Furthermore, results support the criticism of Ball and Shivakumar (2008) that the use of discretionary accruals in the IPO year $\left(\mathrm{DCA}_{0}\right)$ is a biased measure of earnings management. However, consistent with the hypothesis of Teoh et al. (1998), results show that firms with higher discretionary accruals $\left(\mathrm{DCA}_{-1}\right.$ or $\left.\mathrm{DCA}_{0}\right)$ underperform in the long run. The negative relationship between the long-term performance and the level of DCA is robust to several measures of long-term performance (cumulative abnormal returns-CAR, buy-and-hold abnormal returns-BHAR, Fama-French 4-factor model-Alpha), to several time horizons ( 3 and 5 years), and holds even after controlling for several firm characteristics. Overall, the results show that although on average IPO firms don't engage in earnings management, the ones that do, underperform in the long run.
\end{abstract}

Keywords: initial public offerings, earnings management

\section{Introduction}

The effect of company earnings on stock performance is well documented in the finance and accounting literature. Studies show that many companies strive to report high quality earnings. Graham, Harvey and Rajkopal (2005) survey more than 400 company executives and find that managers make an effort to report smooth and predictable earnings. They also find that managers would rather sacrifice firm value than manage earnings. Yet, in certain situations, company insiders have incentives to report higher (or lower) earnings in order to directly benefit from a change in stock price. Equity issuances are an example of corporate events in which insiders have an incentive to artificially boost earnings prior to issuance in order to offer equity at a higher price. Conversely, managers would have an incentive to report lower earnings prior to share repurchases in order to benefit by repurchasing shares at a lower price.

IPOs are particularly interesting corporate events in the context of earnings management because they provide insiders with an incentive to report inflated earnings with minimal litigation risk for doing so. This is due to the high opacity of earnings in the years leading up to the IPO, the drastic changes that the firm goes through during the IPO, and the information asymmetry and uncertainty associated with the IPO.

Several studies have investigated earnings management prior to IPO events. Yet, there is no consensus as to the degree to which firms manage their earnings prior to an IPO and as to what extent such practice affects firm performance. Teoh, Welch, and Wong (1998) [hereafter TWW] proxy for pre-IPO earnings management by using discretionary current accruals in the IPO year $\left(\mathrm{DCA}_{0}\right)$, and find that U.S. IPO firms have significantly positive $\mathrm{DCA}_{0}$. They conclude that, on average, U.S. IPO firms do manage their earnings prior to the IPO event. Furthermore, TWW find that firms with higher $\mathrm{DCA}_{0}$ underperform in the long run, thus, yielding more support for their earnings management hypothesis. 
Although pre-IPO abnormal accruals ( DCA $_{-1}$ ) would make a better proxy to measure the degree of pre-IPO earnings management (Note 1), the calculation of $\mathrm{DCA}_{-1}$ would require data from financial statements two years prior to the IPO which are not available for many firms. To avoid a small sample size, TWW resort to using $\mathrm{DCA}_{0}$ as a proxy for pre-IPO earnings management. They justify the use of $\mathrm{DCA}_{0}$ by arguing that firms that managed earnings prior to the IPO are likely to continue to manage earnings in the IPO year for two reasons. First, as insiders are required to hold their shares for a certain period after the IPO (until the lockup period ends), firms that reported higher pre-IPO earnings are likely to continue to report higher earnings in the IPO-year in order to avoid a price decline. Second, a decline in earnings immediately after the IPO would raise suspicions about earnings management and could result in legal action against the firm. To avoid raising such suspicions managers would continue to report higher earnings in the years following the IPO.

To the contrary, Ball and Shivakumar (2008) [hereafter BS] suggest that, as firms go through the IPO process, they transition from a period of opacity to a period of increased scrutiny regarding earnings. Thus, they have incentives to report conservatively. Using a special sample from U.K. IPO firms, they find support for their hypothesis. Furthermore, they question the results of TWW and theoretically show that $\mathrm{DCA}_{0}$ is a biased measure of pre-IPO earnings management.

Given this ongoing debate regarding the earnings quality of IPO firms, this study examines a sample of 4962 IPOs from 28 countries attempting to answer the following questions.

1) Do firms engage in earnings management prior to an IPO, and, if so, to what degree?

2) Is $\mathrm{DCA}_{0}$ a biased measure of pre-IPO earnings management?

3) Does the degree of pre-IPO earnings management affect the firm's long-term performance?

Analyzing the earnings quality of IPO firms in an international setting is useful in several ways. First, it allows us to calculate $\mathrm{DCA}_{-1}$ for a large sample of IPO firms. The use of $\mathrm{DCA}_{-1}$ as a proxy for pre-IPO earnings management is exempt from most of the criticism of BS (Note 2) and it allows us to better understand the degree of pre-IPO earnings management. Second, the comparison between $\mathrm{DCA}_{-1}$ and $\mathrm{DCA}_{0}$ in an international setting allows us to investigate the seemingly contradictory claims of TWW and BS using an out-of-sample test. Third, by analyzing the degree of earnings management in several countries, we can be more confident that the results are not driven by characteristics that are specific to a single country.

The results show that the degree of earnings management varies by country. In most countries, neither the median nor the mean value of $\mathrm{DCA}_{-1}$ is significantly different from 0 . Furthermore, the countries which report $\mathrm{DCA}_{-1}$ as significantly different from 0 are evenly divided between those which report significantly negative and significantly

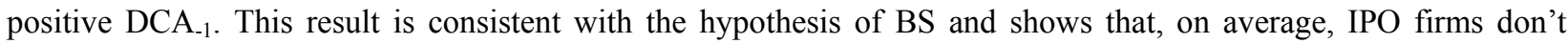
engage in earnings management. However, when $\mathrm{DCA}_{0}$ is used as a proxy for earnings management, the results show support for the earnings management hypothesis: not only do most countries (except Finland) show a positive DCA $_{0}$ on average, but about half of them show significantly positive $\mathrm{DCA}_{0}$. Furthermore, in almost every country (except Belgium, Denmark, and Finland), $\mathrm{DCA}_{0}$ is larger than $\mathrm{DCA}_{-1}$. Statistical tests show that the mean (median) $\mathrm{DCA}_{0}$ is significantly greater than the mean (median) $\mathrm{DCA}_{-1}$ in 10 (12) out of 28 countries. This result supports the criticism of $\mathrm{BS}$ and shows that the use of $\mathrm{DCA}_{0}$ exaggerates the degree of pre-IPO earnings management. Interestingly, Great Britain, from which the sample of BS is taken, shows negative pre-IPO abnormal accruals (consistent with their view that IPO firms have a disincentive to manage earnings), but significantly positive $\mathrm{DCA}_{0}$ (consistent with their criticism). Nevertheless, these results are also consistent with the results of TWW in that most firms report significantly positive $\mathrm{DCA}_{0}$.

To test whether abnormal accruals affect the long-run performance of IPO firms, I use two methods. First, following TWW, I divide firms into quartiles based on their level of DCA and compare the long-term performance of each quartile. Second, I regress IPO long-term abnormal returns on DCA, several control variables that help predict future performance, and country dummies to control for country fixed effects. Consistent with TWW, I find that pre-IPO earnings management helps explain the long-term underperformance of IPO firms. Not only do the IPO firms in the highest quartile of DCA underperform those in the lowest quartile, but the coefficient for the DCA variable is also significantly negative in the regression models. These results are robust to several methods of measuring underperformance (CAR, BHAR, and Alpha), over several time horizons ( 3 and 5 years), to the two measures of earnings management $\left(\mathrm{DCA}_{-1}\right.$ or $\left.\mathrm{DCA}_{0}\right)$, and hold even after controlling for several firm- and country-specific characteristics that could explain IPO underperformance. This result supports the earnings management hypothesis of TWW. 
Overall, I interpret the results of this study as consistent with both seemingly contradictory hypotheses of BS and TWW. Consistent with BS, on average, IPO firms do not engage in pre-IPO earnings management, and $\mathrm{DCA}_{0}$ is a biased measure of pre-IPO earnings management. However, consistent with TWW, some firms do engage in pre-IPO earnings management. These firms are able to deceive investors and receive a higher IPO price; thus, underperform over the long run. Although the use of $\mathrm{DCA}_{0}$ is a biased measure of pre-IPO earnings management, the consistency of the results across both measures of earnings management $\left(\mathrm{DCA}_{-1}\right.$ and $\left.\mathrm{DCA}_{0}\right)$ in explaining IPO underperformance shows that $\mathrm{DCA}_{0}$ may be used, with some caution, as a proxy for earnings management. Perhaps, future studies could develop methods to immunize $\mathrm{DCA}_{0}$ from the criticism of $\mathrm{BS}$.

\section{Literature Review and Hypotheses Development}

IPO underperformance has been well documented in the literature (Note 3), and many studies have tied IPO underperformance to market timing and information asymmetry theories. That is, managers take advantage of their superior information and issue shares at a time when they can receive the highest price possible. Chemmanur and $\mathrm{He}$ (2011), Schaub (2011), Alti (2006), and Brau and Fawcett (2006) support this view by presenting evidence consistent with market timing, and by showing that insiders are able to use inside information to their advantage as these IPOs underperform in the long run.

In addition to timing the market, insiders can also inflate the price of the firm's equity by inflating the firm's earnings prior to the IPO. Higher earnings have a positive effect on equity prices. Although accounting standards guide the way firms report, managers have some discretion when reporting earnings. This discretion includes the choice of accounting method, its application, and the timing of cost recognition. In an IPO setting, managers not only have the incentive to report higher earnings in order to receive a higher IPO price, but also they have the ability to do so because of the opacity that surrounds private firms. TWW proxy for earnings management through $\mathrm{DCA}_{0}$, and find that U.S. firms, on average, manage earnings prior to the IPO. Furthermore, they show that $\mathrm{DCA}_{0}$ is a good predictor of IPO underperformance. This evidence is consistent with managers using their discretion to inflate earnings prior to the IPO, receiving an inflated IPO price, and benefiting at the expense of the new shareholders. Consistent with these results, DuCharme, Malatesta and Sefcik (2001) also find that pre-IPO abnormal accruals result in a significantly higher initial firm value.

BS question the results of TWW and show that, in an IPO setting, when the firm usually experiences a dramatic expansion, the use of $\mathrm{DCA}_{0}$ as a proxy for pre-IPO earnings management is positively biased and it overstates the degree of earnings management. Much of this criticism stems from the fact that DCA are calculated as changes in net working capital (NWC) from two subsequent years and, in the case of $\mathrm{DCA}_{0}$, they are calculated from the change in pre-IPO NWC to the post-IPO NWC. BS show that the change in NWC during the IPO year is not only inflated by the IPO cash infusion, but the IPO firm is also more likely to maintain a higher level of NWC in the post-IPO period to support its higher growth rate. Further, during the calculation of $\mathrm{DCA}_{0}$, the change in NWC is deflated by the pre-IPO total assets which tend to be much lower, and thus resulting in a larger value of $\mathrm{DCA}_{0}$. In addition to criticizing the use of $\mathrm{DCA}_{0}$, $\mathrm{BS}$ argue for an opposite viewpoint. As the firm transitions from the opaque private stage to a transparent and more scrutinized IPO setting, it has an incentive to report higher quality, more conservative earnings. They use a unique sample of U.K. firms to support their claim.

Several other studies have supported this viewpoint. Lubberink and Huijgnen (2006), by using a sample of cross-listed firms, show that firms that also raise capital as part of their cross-listing process report their earnings more conservatively than the ones that cross-list without a capital-raising motive behind their cross-listing. Seger (2009) studies 512 IPOs from 24 countries and finds that firms that are suspected of managing earnings represent only about $10 \%$ of his sample. Xiong, Zhou and Varshney (2010) show that the level of pre-IPO earnings management does not explain IPO firm's long-term underperformance. Furthermore, Roosenboom, van der Goot and Mertens (2003) study a sample of Dutch IPOs and find that these companies manage earnings in the first year as a public company, but not before (consistent with BS). However, unlike Xiong et al. (2010), they find that earnings management in year $0\left(\mathrm{DCA}_{0}\right)$ is a factor in the underperformance of these firms (consistent with TWW). This study can be viewed as a bridge between the contradictory views of TWW and BS as it finds evidence consistent with both.

Although seemingly contradictory, these two hypotheses are not mutually exclusive. It is possible for a firm to report conservatively yet, at the same time, manage earnings to some extent. Givoly, Hayn and Katz (2009) make a distinction between earnings management and reporting conservatism. They measure the degree of earnings management by the persistence and estimation error of accruals and the degree of conservatism through the timeliness of loss recognition. They compare the quality of earnings of private and public companies and find that public firms report more conservatively (consistent with mitigating litigation risk) and simultaneously have higher accruals (consistent with managers having more incentives to act opportunistically and manage earnings). 
Given the ongoing debate about the degree of earnings management of IPO firms, I follow the methodology of TWW to estimate discretionary accruals and thus estimate $\mathrm{DCA}_{-1}$ and $\mathrm{DCA}_{0}$ for every IPO firm in an attempt to find evidence in favor or against the two opposing viewpoints of TWW and BS. Hence, I try to answer the following questions:

1) Do firms engage in earnings management prior to an IPO, and, if so, to what degree?

2) Is $\mathrm{DCA}_{0}$ a biased measure of pre-IPO earnings management?

3) Does the degree of pre-IPO earnings management affect the firm's long-term performance?

\section{Data and Methodology}

I collect data on non-US IPO firms during the period 1988 to 2010 from the Securities Data Corporation (SDC) (Note 4). After deleting duplicate entries, limited partnerships, non-original IPOs, leverage buyout firms, private placements, depositary institutions, closed-end funds, REITs, Units, and entries with a missing SEDOL, I obtain a sample of 15934 IPO firms from 95 countries (Note 5). Financial data on each of these firms and their competitors is collected from Compustat Global. Competitors' data are necessary to calculate DCA. I define a competitor as a firm that operates in the same country, has the same 2-digit SIC code as the IPO firm, and has been a public firm for longer than three years.

Following the methodology of TWW, I calculate DCA $\mathrm{A}_{-1}$ and $\mathrm{DCA}_{0}$ for all IPO firms. Although the focus of this study remains on the pre-IPO abnormal accruals $\left(\mathrm{DCA}_{-1}\right)$, I also discuss the results by using $\mathrm{DCA}_{0}$ as a proxy for earnings management. The use of $\mathrm{DCA}_{0}$ not only serves as a robustness test, but also allows comparing the results with those of TWW and testing whether the use of $\mathrm{DCA}_{0}$ affects the results (as argued by BS). DCA are calculated as follows:

For each IPO firm and its competitors, I estimate current accruals (CA) in each year as:

$\mathrm{CA}=\Delta$ (account receivables + inventory + other current assets $)-\Delta$ (Account payables + taxes payable + other current liabilities)

Then, using only the competitors, I run the following regression model and estimate the coefficients $(\alpha$ and $\beta)$ for each industry-country-year pairing. To ensure a reliable estimator, I only include industries which have at least 15 firms in the country in a given year.

$$
\frac{C A_{j, t}}{T A_{j, t-1}}=\alpha\left(\frac{1}{T A_{j, t-1}}\right)+\beta\left(\frac{\Delta \text { Sales }_{j, t}}{T A_{j, t-1}}\right)+\varepsilon_{j, t}
$$

where $\mathrm{j}$ represents each competitor firm, and TA is the firm's total assets.

Using the estimated coefficients from Eq.2, I calculate the expected (non-discretionary) current accruals (NDCA) for each IPO firm as follows:

$$
\mathrm{NDCA}_{\mathrm{i}, \mathrm{t}}=\hat{\alpha}\left(\frac{1}{T A_{i, t-1}}\right)+\hat{\beta}\left(\frac{\Delta \text { Sales }_{i, t}-\Delta T R_{i, t}}{T A_{i, t-1}}\right)
$$

where i represents each IPO firm and $\triangle \mathrm{TR}$ is the change in trade receivables.

The IPO firm discretionary (abnormal) current accruals (DCA) are calculated as follows:

$$
\mathrm{DCA}_{\mathrm{i}, \mathrm{t}}=\frac{C A_{i, t}}{T A_{i, t-1}}-N D C A_{i, t}
$$

In order to estimate DCA in year -1, accounting data for the two years prior to the IPO are required, which are not available for some firms. Furthermore, in countries with undeveloped capital markets there are many industries with very few public firms in a given year. These restrictions reduce the sample size to 28 countries, and I am able to calculate the $\mathrm{DCA}_{-1}$ and $\mathrm{DCA}_{0}$ for 2964 and 4962 IPO firms respectively.

To test whether the degree of earnings management affects long-term firm performance, I run several tests. The IPO firm's long term performance is measured over 3 and 5 year horizons following the IPO date. Naturally, the sample size of IPO firms gets smaller when the period over which long-term performance is assessed lengthens. The IPO firm's long-term performance is captured by each of the following three measures:

\section{Cumulative Abnormal Returns:}

$$
C A R_{i, t}=\sum_{t=1}^{t} A R_{i, t}
$$

Where $A R_{i, t}=R_{i, t}-R m_{t}, R_{i, t}$ is the return of the IPO firm, and $R m_{t}$ is the return of the Datastream's country market index (using TOTMK mnemonic). 


\section{Buy and Hold Abnormal Returns:}

$$
B H A R_{i, t}=\prod_{\mathrm{t}=1}^{\mathrm{t}}\left(1+R_{i, t}\right)-\prod_{\mathrm{t}=1}^{\mathrm{t}}\left(1+R m_{t}\right)
$$

Where $R_{i, t}$ is the return of the IPO firm, and $R m_{t}$ is the return of the Datastream's country market Index (using TOTMK mnemonic).

\section{Fama and French Four-Factor Model:}

$$
R_{i, t}-R_{f t}=\alpha_{i}+\beta_{i}\left(R_{m t}-R_{f t}\right)+s_{i} S M B_{t}+h_{i} H M L_{t}+w_{i} W M L+\varepsilon_{i, t}
$$

Where $R m_{t}$ is the return of the continent's market index in month $\mathrm{t} ; R_{f t}$ is the return of the continent's risk-free rate in month $\mathrm{t} ; S M B_{t}$ is the difference in the returns between the continent's portfolio of small stocks and big stocks in month $\mathrm{t} ; H M L_{t}$ is the difference in the returns between the continent's portfolio of high book-to-market stocks and low book-to-market firms in month t; and $W M L$ is the difference in the returns between the continent's portfolio of winner stocks and loser stocks in month t. The coefficient $\alpha_{i}$ (which is referred to as "Alpha" throughout the paper) represents the average monthly abnormal return. The model is run twice, i.e., with continental factors (denoted with Alpha in the tables), and with the global factors (denoted as GAlpha in the tables). The continental factors represent the factors for the continent in which the firm operates while the global factors represent the factors for all the continents combined. This data is downloaded from Kenneth French's website (Note 6).

\begin{tabular}{|c|c|c|c|c|c|c|c|c|c|c|c|c|}
\hline \multirow[b]{2}{*}{ Country } & \multicolumn{2}{|c|}{ Mean } & \multicolumn{2}{|c|}{ Median } & \multicolumn{2}{|c|}{$\begin{array}{l}\text { Standard } \\
\text { Deviation }\end{array}$} & \multicolumn{2}{|c|}{$\begin{array}{l}\text { Number of } \\
\text { Firms }\end{array}$} & \multicolumn{2}{|c|}{$\begin{array}{l}\text { T-stat (T-Test for } \\
\text { the Mean) }\end{array}$} & \multicolumn{2}{|c|}{$\begin{array}{l}\text { Z-stat (Wilcoxon's } \\
\text { Signed Rank Test) }\end{array}$} \\
\hline & $\mathrm{DCA}_{-1}$ & $\mathrm{DCA}_{0}$ & $\mathrm{DCA}_{1}$ & $\mathrm{DCA}_{0}$ & $\mathrm{DCA}_{-1}$ & $\mathrm{DCA}_{0}$ & $\mathrm{DCA}_{-1}$ & $\mathrm{DCA}_{0}$ & DCA $_{-1}$ & $\mathrm{DCA}_{0}$ & DCA $_{-1}$ & $\mathrm{DCA}_{0}$ \\
\hline Australia & -0.072 & 0.037 & -0.018 & 0.000 & 0.346 & 0.408 & 237 & 591 & $-3.209 * * *$ & $2.227^{* *}$ & $-2.977 * * *$ & 1.403 \\
\hline Austria & 0.027 & 0.132 & 0.023 & 0.077 & 0.086 & 0.274 & 4 & 8 & 0.635 & 1.361 & 0.730 & 1.400 \\
\hline Belgium & 0.113 & 0.054 & 0.040 & 0.033 & 0.164 & 0.304 & 14 & 18 & $2.571^{* *}$ & 0.756 & $2.103^{* *}$ & 0.980 \\
\hline Brazil & 0.029 & 0.183 & 0.013 & 0.062 & 0.313 & 0.380 & 24 & 26 & 0.459 & $2.461 * *$ & 1.126 & $2.021^{* *}$ \\
\hline Switzerland & -0.101 & 0.051 & 0.026 & 0.004 & 0.294 & 0.214 & 9 & 22 & -1.026 & 1.125 & -0.421 & 0.373 \\
\hline China & 0.011 & 0.097 & 0.017 & 0.077 & 0.201 & 0.223 & 904 & 1017 & 1.596 & $13.923 * * *$ & $3.447 * * *$ & $14.292 * * *$ \\
\hline Germany & -0.057 & 0.102 & -0.031 & 0.071 & 0.326 & 0.383 & 100 & 270 & $-1.757^{*}$ & $4.387 * * *$ & -1.561 & $4.239 * * *$ \\
\hline Denmark & 0.066 & 0.053 & -0.036 & 0.067 & 0.246 & 0.272 & 15 & 34 & 1.044 & 1.127 & 0.568 & 1.120 \\
\hline Spain & 0.053 & 0.111 & 0.049 & 0.071 & 0.242 & 0.239 & 7 & 12 & 0.574 & 1.607 & 0.338 & 1.726 \\
\hline Finland & 0.043 & -0.001 & -0.019 & -0.013 & 0.226 & 0.275 & 6 & 22 & 0.469 & -0.020 & -0.524 & -0.146 \\
\hline France & 0.005 & 0.072 & 0.003 & 0.044 & 0.215 & 0.290 & 110 & 227 & 0.243 & $3.743 * * *$ & 0.172 & $3.722^{* * *}$ \\
\hline Great Britain & -0.024 & 0.047 & -0.007 & 0.018 & 0.302 & 0.371 & 278 & 544 & -1.349 & $2.936 * * *$ & -1.320 & $2.492 * *$ \\
\hline Greece & -0.018 & 0.115 & 0.052 & 0.074 & 0.197 & 0.386 & 3 & 9 & -0.158 & 0.896 & 0.000 & 1.125 \\
\hline Hong-Kong & 0.003 & 0.102 & 0.006 & 0.077 & 0.260 & 0.283 & 54 & 63 & 0.096 & $2.849 * * *$ & 0.040 & $2.854 * * *$ \\
\hline India & 0.109 & 0.129 & 0.094 & 0.104 & 0.249 & 0.309 & 233 & 254 & $6.666 * * *$ & $6.662 * * *$ & $6.913^{* * *}$ & $6.454^{* * *}$ \\
\hline Ireland & -0.289 & 0.170 & -0.248 & 0.061 & 0.261 & 0.417 & 6 & 11 & $-2.710^{* *}$ & 1.350 & $-1.997^{*}$ & 1.514 \\
\hline Italy & -0.003 & 0.087 & 0.000 & 0.052 & 0.191 & 0.247 & 39 & 78 & -0.104 & $3.127^{* * *}$ & -0.656 & $3.145^{* * *}$ \\
\hline Japan & -0.017 & 0.022 & -0.003 & 0.012 & 0.152 & 0.133 & 468 & 809 & $-2.462^{* *}$ & $4.651^{* * *}$ & $-1.749 *$ & $4.927^{* * *}$ \\
\hline South Korea & -0.015 & 0.064 & -0.003 & 0.060 & 0.166 & 0.175 & 7 & 19 & -0.241 & 1.594 & -0.338 & 1.489 \\
\hline Mexico & -0.038 & 0.029 & -0.012 & 0.016 & 0.186 & 0.084 & 11 & 15 & -0.675 & 1.345 & -0.889 & 1.306 \\
\hline Malysia & 0.015 & 0.111 & 0.036 & 0.080 & 0.262 & 0.241 & 33 & 165 & 0.327 & $5.903 * * *$ & 0.187 & $6.089 * * *$ \\
\hline Holland & 0.034 & 0.053 & 0.057 & 0.084 & 0.337 & 0.296 & 14 & 32 & 0.374 & 1.017 & 0.911 & 1.384 \\
\hline Norway & -0.046 & 0.036 & -0.036 & 0.001 & 0.268 & 0.325 & 22 & 38 & -0.803 & 0.680 & -0.958 & 0.196 \\
\hline New Zealand & -0.011 & 0.015 & 0.013 & 0.009 & 0.293 & 0.241 & 9 & 17 & -0.113 & 0.253 & 0.770 & 0.260 \\
\hline Singapore & 0.005 & 0.114 & 0.032 & 0.087 & 0.282 & 0.294 & 116 & 226 & 0.203 & $5.820 * * *$ & 0.798 & $5.840 * * *$ \\
\hline Sweden & 0.005 & 0.050 & -0.010 & 0.037 & 0.281 & 0.267 & 20 & 42 & 0.078 & 1.216 & 0.000 & 1.144 \\
\hline Thailand & -0.028 & 0.098 & -0.006 & 0.063 & 0.225 & 0.237 & 21 & 68 & -0.566 & $3.395 * * *$ & -0.295 & $3.727^{* * *}$ \\
\hline Taiwan & 0.025 & 0.034 & 0.020 & 0.027 & 0.142 & 0.150 & 200 & 325 & $2.517^{* *}$ & $4.072^{* * *}$ & $2.908 * *$ & $4.862^{* * *}$ \\
\hline
\end{tabular}

Table 1. DCA description

This table summarizes discretionary current accruals $\left(\mathrm{DCA}_{-1}\right.$ and $\left.\mathrm{DCA}_{0}\right)$ by country. The left eight columns provide the descriptive statistics, while the right four columns provide the test statistics that test whether the DCA for each country are statistically different from 0 (mean or median). ${ }^{*}, *$, and $* * *$ represent the level of significance at 10,5 , and $1 \%$, respectively. 


\section{Results}

\subsection{Univariate Results - Degree of Earnings Management for Each Country}

Table 1 shows the descriptive statistics of DCA for each country and the results of several tests to distinguish whether DCA in each country are significantly different from 0 (Note 7). This table shows that $\mathrm{DCA}_{0}$ is greater than DCA $_{-1}$ (both mean and median) in 25 out of 28 countries. Statistical tests show that the mean (median) $\mathrm{DCA}_{0}$ is significantly greater than the mean (median) DCA $_{-1}$ in 10 (12) out of 28 countries (Note 8). Furthermore, while there are many countries that have negative $\mathrm{DCA}_{-1}$, only Finland (both mean and median) and Australia (median) have negative $\mathrm{DCA}_{0}$. These results are consistent with the criticism of BS and provide evidence that the use of $\mathrm{DCA}_{0}$ is a biased estimator of pre-IPO earnings management. The results also show that there is a large variation in both $\mathrm{DCA}_{-1}$ and $\mathrm{DCA}_{0}$ in each country. The large standard deviation of DCA indicates that, even within country, the degree of earnings management depends on the firm's characteristics and that some firms might have stronger incentives and opportunities to manage earnings. In regards to $\mathrm{DCA}_{-1}$ this could mean that while on average IPO firms don't engage in earnings management, some firms might be able to successfully manage earnings in order to receive a higher IPO price. If these firms are able to deceive investors and receive a higher IPO price, we should observe greater underperformance for these firms. We explore this relationship in the next section.

The two rightmost panels of Table 1 show the results of a series of t-tests and Wilcoxon's signed rank tests conducted in each country in order to examine whether DCA are significantly different from 0 . The results of both tests yield similar results, and show that $\mathrm{DCA}_{-1}$ are not different from 0 in most countries. The t-test shows that $\mathrm{DCA}_{-1}$ are significantly negative in 4 countries and significantly positive in 2 countries, while the Wilcoxon signed rank test shows that $\mathrm{DCA}_{-1}$ are significantly negative in 3 countries and significantly positive in 4 countries. Inconsistent with the findings of TWW and consistent with those of BS, these results show that IPO firms, on average, are unlikely to have managed earnings prior to the IPO. When $\mathrm{DCA}_{0}$ are used as a proxy for earnings management, the t-test and the Wilcoxon signed rank test yield similar results and show that about half of the countries have significantly positive $\mathrm{DCA}_{0}$, and no country has significantly negative $\mathrm{DCA}_{0}$. These results further support the hypothesis of $\mathrm{BS}$ that the use of $\mathrm{DCA}_{0}$ is a biased estimator of pre-IPO earnings management.

\subsection{Effect of Earnings Management on IPO Long-Term Performance}

If some IPO firms are able to manage their earnings and mislead investors, then we should observe a negative relationship between DCA and the IPO firm's long-term performance. To test whether earnings management affects the long term performance of IPO firms, I run several univariate and multivariate tests.

Following TWW, the sample is divided into quartiles based on the magnitude of earnings management (size of DCA). Table 2 reports the median long-term abnormal performance for each DCA quartile. The top panel shows the results based on the use of $\mathrm{DCA}_{-1}$ as a proxy for earnings management. Although results show that firms that manage earnings more aggressively (quartile 4) underperform the least aggressive firms (quartile 1) across all measures of abnormal performance, the firms that manage earnings more aggressively are not the worst performing group when the long term performance is measured by the Fama-French 4 factor model. These results are partially consistent with the hypothesis of TWW.

The bottom panel shows the results based on the use of $\mathrm{DCA}_{0}$ as a proxy for earnings management. Similar to prior results, the IPO firms that manage earnings more aggressively (quartile 4) underperform the least aggressive firms (quartile 1) across all measures of abnormal performance. However, unlike the prior results, the most aggressive quartile is always the worst performing group. These results are entirely consistent with the findings of TWW and show that IPO firms that manage their earnings are able to benefit from such practice. 
Table 2. Median long-term abnormal returns by DCA quartiles

\begin{tabular}{|c|c|c|c|c|c|c|c|c|}
\hline \multicolumn{9}{|c|}{ Abnormal Performance Based Upon DCA 1 Quartiles } \\
\hline DCA $_{-1}$ Quartile & CAR3 & CAR5 & BHAR3 & BHAR5 & Alpha3 & Alpha5 & GAlpha3 & GAlpha5 \\
\hline 1 (Lowest) & 0.0745 & 0.1672 & -0.1306 & -0.3586 & 0.0034 & 0.0069 & 0.0021 & 0.0056 \\
\hline 2 & 0.0334 & 0.2006 & -0.1536 & -0.1514 & 0.0030 & 0.0057 & 0.0029 & 0.0042 \\
\hline 3 & 0.0360 & 0.1896 & -0.1584 & -0.2476 & 0.0014 & 0.0056 & 0.0015 & 0.0037 \\
\hline 4 (Highest) & -0.0198 & 0.0782 & -0.3148 & -0.4803 & 0.0027 & 0.0064 & 0.0017 & 0.0045 \\
\hline Total & -0.0001 & 0.1518 & -0.2408 & -0.2942 & 0.0023 & 0.0063 & 0.0020 & 0.0045 \\
\hline \multicolumn{9}{|c|}{ Abnormal Performance Based Upon DCA 0 Quartiles } \\
\hline DCA $_{0}$ Quartile & CAR3 & CAR5 & BHAR3 & BHAR5 & Alpha3 & Alpha5 & GAlpha3 & GAlpha5 \\
\hline 1 (Lowest) & 0.0074 & 0.1474 & -0.3246 & -0.4597 & 0.0023 & 0.0049 & -0.0012 & 0.0033 \\
\hline 2 & -0.0368 & 0.1429 & -0.2323 & -0.2812 & -0.0011 & 0.0042 & -0.0003 & 0.0020 \\
\hline 3 & -0.0479 & 0.1024 & -0.2754 & -0.3472 & 0.0006 & 0.0039 & -0.0004 & 0.0025 \\
\hline 4 (Highest) & -0.1481 & -0.0473 & -0.4370 & -0.5907 & -0.0017 & 0.0027 & -0.0039 & -0.0001 \\
\hline Total & -0.0507 & 0.0870 & -0.3116 & -0.4215 & -0.0001 & 0.0039 & -0.0014 & 0.0018 \\
\hline
\end{tabular}

This table reports the median abnormal return across several measures and several time horizons for each DCA quartile. The DCA quartiles are calculated for each country separately. Each column represents a different measure of long term abnormal return (CAR, BHAR, Alpha, or GAlpha) in the 3 and 5 year period following the IPO (the period longevity is indicated by the number that follows each abnormal return measure). The top panel shows the results for quartiles divided based on the magnitude of $\mathrm{DCA}_{-1}$, while the bottom panel shows the results for quartiles divided based on the magnitude of $\mathrm{DCA}_{0}$.

The underperformance of IPO firms could also be due to firm characteristics and its operating performance. To ensure that the results are not driven by other factors that could affect the long-term performance of IPOs, I control for several firm and country characteristics by running the following regression model:

AbnormalReturn $_{i}=\alpha+\beta_{1}$ DCA $_{i}+\beta_{2}$ SalesGrowth $_{i}+\beta_{3}$ ROAGrowth $_{i}+\beta_{4}$ UWrank $_{i}+\beta_{5}$ LogAssets $_{i}+\beta_{6}$ Lockup $_{i}+\beta_{7}$ $\mathrm{VC}_{\mathrm{i}}+\beta_{8} \mathrm{ADR}_{\mathrm{i}}+$ CountryDummies $+\varepsilon_{\mathrm{I}}$

(Eq. 8)

Where:

AbnormalReturn is the IPO firm long-term abnormal performance. I use several measures of long term performance (CAR, BHAR, Alpha, and AlphaG), over two time horizons ( 3 and 5 years).

DCA is the estimate of discretionary current accruals of the IPO firm. I run 2 versions of the model, and interchangeably use $\mathrm{DCA}_{-1}$ and $\mathrm{DCA}_{0}$ as a proxy for earnings management. This is the main variable of interest, and, if earnings management affects the firm long-term performance, we should expect a negative coefficient.

SalesGrowth is the geometric average of sales' growth during the first 3 post-IPO years. This variable is included as a proxy for growth opportunities (Note 9). A positive coefficient is expected for this variable as firms with higher growth opportunities not only have a better use for the cash raised through the IPO, but they are also less likely to have managed their earnings since they strive to maintain high credibility in capital markets.

ROAGrowth is the geometric average growth of return on assets during the first 3 post-IPO years. It measures the firm's operating performance and is expected to be positively related to AbnormalReturn.

UWrank is the measure of the underwriter's reputation. This is taken from Jay Ritter's web page (Note 10), which reports the underwriter rankings following the method of Carter and Manaster (1990). If the firm's underwriter is not ranked, it is likely to be a small, local underwriter with little reputation, and a ranking of 0 is assigned. If the reputable underwriters are able to select the highest quality IPO firms, a positive relationship between 
underwriter ranking and IPO long term performance is expected. Lee et al. (2012) find support consistent with this hypothesis.

LogAssets is the natural logarithm of firm total assets in year 0 .

Lockup is a dummy variable that equals 1 if the IPO has a lockup period and 0 otherwise. If the IPO has a lockup period, it would take longer for firm insiders to benefit from their information asymmetry advantage. As a result, insiders might have their interests better aligned with outside investors, and therefore, stronger long-term performance is expected. However, lower quality IPOs might be required to include a lockup period as a way to earn the confidence and interest from new investors. If the lockup period is more likely for lower quality firms, then a negative relationship is expected.

$\mathrm{VC}$ is a dummy variable that equals 1 if the firm is backed by a venture capitalist and 0 otherwise. Venture capitalists may use their expertise in selecting higher quality firms. This hypothesis would predict a positive coefficient for VC. However, venture capitalists may also use their expertise in timing the market and taking the firm public at a time when they can cash out at the highest possible price. This hypothesis would predict a negative coefficient for VC.

ADR is a dummy variable that equals 1 if the firm also lists on a US exchange, and 0 otherwise. By listing in the U.S., foreign IPOs expose themselves to a higher level of regulation and monitoring. Thus, not only are these firms less likely to engage in earnings management, but higher reporting standards also ensure that managers are more likely to act in the best interest of shareholders. For these reasons, ADR-IPOs should perform better and a positive coefficient is expected. Conversely, by listing in the U.S., IPO firms can reduce the degree of market segmentation and broaden their investor base. This lowers their cost of capital, and lower returns would be expected in the future. This hypothesis predicts that ADR-IPOs underperform in the long run and a negative coefficient it expected.

CountryDummies: The model includes country dummies to capture the country-specific fixed effects that might affect the performance of IPOs.

Table 3 reports the results of the regression models run with $\mathrm{DCA}_{-1}$ as the proxy for earnings management. To ensure the comparability of results, all firm-specific variables are expressed in US Dollars, and to avoid heteroskedasticity, all the t-statistics are calculated by using robust standard errors as in White (1980). Consistent with TWW, the coefficient of DCA-1 is consistently negative and it is significant in 5 out of 8 models. This result shows that firms that manage earnings prior to the IPO are able to artificially inflate the IPO price and thus, they underperform in the long run. This underperformance is robust to several methods of calculating long term performance, several time horizons, and persists after controlling for other firm and country variables.

The coefficient of SalesGrowth, is consistently positive and it is significant in 7 out of 8 models. This result is consistent with the hypothesis that firms with more growth opportunities put their funds raised through the IPO to better use, and, therefore, have better long term performance. These firms are also less likely to engage in earnings management as they may need to remain credible in capital markets for future capital-raising efforts.

The coefficient of ROAGrowth is positive and significant in all the eight models. Firms with the highest operating performance also experience significantly higher stock performance.

The coefficient of UWrank is insignificant in all the models. This result shows that the underwriter reputation doesn't affect the firm's long-term performance.

The coefficient of LogAssets is consistently negative and it is significant in 5 out of 8 models. This result shows that the largest IPO firms tend to underperform over the long run. 
Table 3. Cross-sectional regression for abnormal performance (using DCA A $_{-1}$

\begin{tabular}{|c|c|c|c|c|c|c|c|c|}
\hline \multirow[b]{3}{*}{$\begin{array}{l}\text { Independent } \\
\text { Variables }\end{array}$} & \multicolumn{8}{|c|}{ Dependent Variable } \\
\hline & \multirow[t]{2}{*}{ CAR3 } & \multirow[t]{2}{*}{ CAR5 } & \multirow[t]{2}{*}{ BHAR3 } & \multirow[t]{2}{*}{ BHAR5 } & \multirow[t]{2}{*}{ Alpha3 } & \multirow[t]{2}{*}{ Alpha5 } & \multirow[t]{2}{*}{ GAlpha3 } & \multirow[t]{2}{*}{ GAlpha5 } \\
\hline & & & & & & & & \\
\hline \multirow[t]{2}{*}{ Constant } & $0.158 * *$ & $0.481 * * *$ & $0.220 *$ & $0.480 * *$ & $0.00858 * * *$ & $0.0131 * * *$ & $0.00910 * * *$ & $0.00989 * * *$ \\
\hline & (2.36) & $(5.62)$ & (1.91) & $(2.50)$ & (3.45) & (7.21) & (3.70) & $(5.63)$ \\
\hline \multirow[t]{2}{*}{$\mathrm{DCA}_{-1}$} & -0.0228 & $-0.292 * * *$ & -0.0272 & -0.121 & $-0.00698 * *$ & $-0.00758 * * *$ & $-0.00604 * *$ & $-0.00761 * * *$ \\
\hline & $(-0.28)$ & $(-2.81)$ & $(-0.19)$ & $(-0.52)$ & $(-2.29)$ & $(-3.45)$ & $(-2.00)$ & $(-3.56)$ \\
\hline \multirow[t]{2}{*}{ SalesGrowth } & $0.00842 * * *$ & $0.00544 \%$ & $0.0195 * * *$ & 0.00983 & $0.000227 * *$ & $0.000144 * *$ & $0.000190 * *$ & $0.000123 *$ \\
\hline & (3.34) & (1.75) & (4.49) & $(1.41)$ & (2.42) & (2.19) & $(2.05)$ & (1.92) \\
\hline \multirow[t]{2}{*}{ ROAGrowth } & $0.0902 * * *$ & $0.108 * * *$ & $0.0631 *$ & $0.105 *$ & $0.00335 * * *$ & $0.00236 * * *$ & $0.00297 * * *$ & $0.00216 * * *$ \\
\hline & $(4.05)$ & (3.93) & $(\mathbf{1 . 6 5})$ & (1.71) & (4.07) & (4.11) & (3.64) & (3.85) \\
\hline \multirow[t]{2}{*}{ UWRank } & 0.00814 & 0.00318 & 0.0208 & 0.00332 & 0.000396 & -0.0000195 & -0.000129 & 0.0000195 \\
\hline & $(0.64)$ & $(0.20)$ & $(0.94)$ & $(0.09)$ & $(0.82)$ & $(-0.06)$ & $(-0.28)$ & $(0.06)$ \\
\hline \multirow[t]{2}{*}{ LogAssets } & -0.0218 & $-0.0660 * * *$ & -0.0358 & $-0.0779 *$ & -0.000749 & $-0.00119 * * *$ & $-0.000994 *$ & $-0.000989 * *$ \\
\hline & $(-1.46)$ & $(-3.44)$ & $(-1.39)$ & $(-1.81)$ & $(-1.34)$ & $(-2.92)$ & $(-1.80)$ & $(-2.51)$ \\
\hline \multirow[t]{2}{*}{ Lockup } & 0.0254 & 0.0178 & -0.204 & -0.279 & 0.00161 & -0.00208 & 0.000677 & -0.00108 \\
\hline & $(0.33)$ & $(0.18)$ & $(-1.53)$ & $(-1.24)$ & $(0.56)$ & $(-0.98)$ & $(0.24)$ & $(-0.52)$ \\
\hline \multirow[t]{2}{*}{$\mathrm{VC}$} & $-0.219 * * *$ & $-0.197 * *$ & $-0.223 *$ & -0.134 & $-0.0119 * * *$ & $-\mathbf{0 . 0 0 7 5 3 * * *}$ & $-0.00909 * * *$ & $-0.00467 * * *$ \\
\hline & $(-3.28)$ & $(-2.33)$ & $(-1.94)$ & $(-0.71)$ & $(-4.84)$ & $(-4.23)$ & $(-3.71)$ & $(-2.69)$ \\
\hline \multirow[t]{2}{*}{ ADR } & $0.213 * *$ & $0.256 * *$ & $0.281 *$ & $0.829 * * *$ & 0.00478 & $0.00684 * * *$ & 0.0052 & $0.00606 * * *$ \\
\hline & $(2.39)$ & $(2.23)$ & $(1.83)$ & $(3.22)$ & $(1.42)$ & $(2.78)$ & $(1.59)$ & $(2.58)$ \\
\hline \multicolumn{9}{|l|}{ Country } \\
\hline \multicolumn{9}{|l|}{ Fixed } \\
\hline Effects & Yes & Yes & Yes & Yes & Yes & Yes & Yes & Yes \\
\hline $\mathrm{N}$ & 2431 & 2297 & 2431 & 2297 & 2406 & 2274 & 2431 & 2297 \\
\hline $\mathrm{R}-\mathrm{sq}$ & 0.020 & 0.021 & 0.016 & 0.009 & 0.023 & 0.030 & 0.017 & 0.022 \\
\hline
\end{tabular}

This table shows the results of the cross-sectional regressions used to explain the long-term performance of IPO firms. In each model, the dependent variable is a measure of long-term abnormal return (CAR, BHAR, Alpha, or GAlpha) in the 3 and 5 year period following the IPO (the period longevity is indicated by the number that follows each abnormal return measure). The t-statistics are shown in brackets. *, **, and *** represent the level of significance at 10,5 , and $1 \%$, respectively.

The coefficient of VC is consistently negative and it is significant in 7 out of 8 models. This result strongly supports the hypothesis that venture capitalists are able to time the market and take the firm public at an optimal time.

The coefficient for ADR is consistently positive and it is significant in 6 out of 8 models. This outcome supports the hypothesis that ADR-IPOs expose themselves to greater scrutiny and regulation. By launching an ADR-IPO, such 
firms earn a reputation as high quality firms that are unlikely to engage in such deceitful practices as earnings management (Note 11).

Table 4. Cross-sectional regression for abnormal performance (using $\mathrm{DCA}_{0}$ )

\begin{tabular}{|c|c|c|c|c|c|c|c|c|}
\hline \multirow[b]{3}{*}{$\begin{array}{l}\text { Independent } \\
\text { Variables }\end{array}$} & \multicolumn{8}{|c|}{ Dependent Variable } \\
\hline & \multirow[t]{2}{*}{ CAR3 } & \multirow[t]{2}{*}{ CAR5 } & \multirow[t]{2}{*}{ BHAR3 } & \multirow[t]{2}{*}{ BHAR5 } & \multirow[t]{2}{*}{ Alpha3 } & \multirow[t]{2}{*}{ Alpha5 } & \multirow[t]{2}{*}{ GAlpha3 } & \multirow[t]{2}{*}{ GAIpha5 } \\
\hline & & & & & & & & \\
\hline \multirow[t]{2}{*}{ Constant } & $0.141 * *$ & $0.450 * * *$ & $0.199 * *$ & $0.731 * *$ & $0.00683^{* * *}$ & $0.0115^{* * *}$ & $0.00723 * * *$ & $0.00913 * * *$ \\
\hline & $(2.50)$ & $(6.44)$ & (2.05) & (2.18) & (3.35) & (8.10) & (3.61) & (6.66) \\
\hline \multirow[t]{2}{*}{$\mathrm{DCA}_{0}$} & $-0.153 * *$ & $-0.326 * * *$ & -0.129 & -0.24 & $-0.00817 * * *$ & $-0.00804 * * *$ & $-0.00712^{* * *}$ & $-0.00805 * * *$ \\
\hline & $(-2.46)$ & $(-4.28)$ & $(-1.21)$ & $(-0.65)$ & $(-3.65)$ & $(-5.18)$ & $(-3.24)$ & $(-5.38)$ \\
\hline \multirow[t]{2}{*}{ SalesGrowth } & $0.00609 * * *$ & $0.00438^{* *}$ & $0.0112 * * *$ & 0.00665 & $0.000291 * * *$ & $0.000139 * * *$ & $0.000199 * * *$ & $0.0001000 * *$ \\
\hline & (3.53) & $(2.10)$ & (3.77) & $(0.66)$ & $(4.69)$ & (3.29) & (3.25) & $(2.45)$ \\
\hline \multirow[t]{2}{*}{ ROAGrowth } & $0.127 * * *$ & $0.142^{* * *}$ & $0.0859 * * *$ & 0.15 & $0.00393 * * *$ & $0.00245^{* * *}$ & $0.00374 * * *$ & $0.00246 * * *$ \\
\hline & $(6.98)$ & $(6.06)$ & (2.76) & (1.36) & $(6.05)$ & (5.16) & (5.82) & (5.35) \\
\hline \multirow[t]{2}{*}{ UWRank } & 0.00276 & 0.0151 & 0.00958 & -0.00926 & 0.000189 & 0.000144 & -0.000304 & 0.000145 \\
\hline & $(0.24)$ & $(1.05)$ & $(0.48)$ & $(-0.13)$ & $(0.44)$ & $(0.49)$ & $(-0.73)$ & $(0.51)$ \\
\hline \multirow[t]{2}{*}{ LogAssets } & $-0.0293 * *$ & $-0.0705 * * *$ & $-0.0431^{*}$ & $-0.146^{*}$ & $-0.00109 * *$ & $-0.00138 * * *$ & $-0.00149 * * *$ & $-0.00151 * * *$ \\
\hline & $(-2.27)$ & $(-4.41)$ & $(-1.94)$ & $(-1.89)$ & $(-2.34)$ & $(-4.24)$ & $(-3.26)$ & $(-4.80)$ \\
\hline \multirow[t]{2}{*}{ Lockup } & 0.0999 & 0.0489 & -0.1 & -0.187 & 0.00448 & -0.000748 & 0.00285 & 0.000465 \\
\hline & $(1.25)$ & $(0.49)$ & $(-0.73)$ & $(-0.39)$ & $(1.55)$ & $(-0.36)$ & $(1.01)$ & $(0.24)$ \\
\hline \multirow[t]{2}{*}{$\mathrm{VC}$} & $-0.239 * * *$ & $-0.244 * * *$ & $-0.226^{* *}$ & -0.292 & $-0.0115^{* * *}$ & $-0.00761 * * *$ & $-0.00768 * * *$ & $-0.00415^{* *}$ \\
\hline & $(-3.59)$ & $(-2.96)$ & $(-1.98)$ & $(-0.74)$ & $(-4.77)$ & $(-4.54)$ & $(-3.25)$ & $(-2.57)$ \\
\hline \multirow[t]{2}{*}{$\mathrm{ADR}$} & $0.355^{* * *}$ & $0.403^{* * *}$ & $0.786^{* * *}$ & $1.061^{* *}$ & $0.0100 * * *$ & $0.0101 * * *$ & $0.00884 * * *$ & $0.00791 * * *$ \\
\hline & $(4.56)$ & $(4.20)$ & $(5.90)$ & $(2.31)$ & (3.54) & $(5.11)$ & (3.22) & $(4.21)$ \\
\hline \multicolumn{9}{|l|}{ Country } \\
\hline Fixed Effects & Yes & Yes & Yes & Yes & Yes & Yes & Yes & Yes \\
\hline $\mathrm{N}$ & 4048 & 3876 & 4048 & 3876 & 4019 & 3849 & 4048 & 3876 \\
\hline R-sq & 0.027 & 0.027 & 0.017 & 0.003 & 0.029 & 0.033 & 0.022 & 0.028 \\
\hline
\end{tabular}

This table shows the results of the cross-sectional regressions used to explain the long-term performance of IPO firms. In each model, the dependent variable is a measure of long-term abnormal return (CAR, BHAR, Alpha, or GAlpha) in the 3 and 5 year period following the IPO (the period longevity is indicated by the number that follows each abnormal return measure). The t-statistics are shown in brackets. *,**, and ${ }^{* * *}$ represent the level of significance at 10,5 , and $1 \%$, respectively.

Table 4 reports the results of the regression models run with $\mathrm{DCA}_{0}$ as a proxy for earnings management. The results are very similar to the results reported in Table $3 . \mathrm{DCA}_{0}$ is consistently negative and it is significant in 6 out of the 8 
models. This is the main variable of interest, and, consistent with TWW, results show that firms that manage earnings more aggressively underperform over the long run.

Similarly to Table 3 results, firms with greater investment opportunities (SalesGrowth), firms with higher profitability (ROAGrowth), and ADR-IPOs perform significantly better other firms. The coefficients of SalesGrowth, ROAGrowth and ADR are consistently positive and they are significant in 7 out of 8 models (ADR is significant in all 8 models).

Consistent with Table 3 results, larger firms (LogAssets) and firms backed by a venture capitalist (VC), underperform over the long run. The coefficients of LogAssets and VC are negative and significant in most models. Similar to prior results, the coefficients of UWRank and Lockup are insignificant in all models.

Overall, I interpret the above results as consistent with both the opposing views of BS and TWW as well as with the results of Roosenboom et al. (2003). Consistent with BS and Roosenboom et al. (2003), IPO firms are unlikely to manage earnings prior to the IPO and, consistent with $\mathrm{BS}$ ' criticism, the use of $\mathrm{DCA}_{0}$ exaggerates the degree of earnings management. However, although the average IPO firm is unlikely to engage in earnings management, the firms which manage earnings more aggressively receive an inflated IPO price are able to benefit from it. This leads to underperformance in the long-run, which is consistent with TWW.

The consistency of results among several measures of abnormal performance, several time periods, and several measures of degree of earnings management not only supports the TWW hypothesis that firms that manage earnings more aggressively underperform over the long run, but also shows that the use of $\mathrm{DCA}_{0}$ is justified as a proxy for earnings management when applied to measuring the performance of IPO firms. However, some caution needs to be exercised when using $\mathrm{DCA}_{0}$ as a proxy for earnings management. Consistent with the criticism of $\mathrm{BS}$, the results of this paper show that $\mathrm{DCA}_{0}$ is a biased proxy of earnings management.

\section{Robustness Check}

To further ensure the robustness of the results, and to better preserve the comparability of results among both measures of earnings management $\left(\mathrm{DCA}_{-1}\right.$ and $\left.\mathrm{DCA}_{0}\right)$, I recalculate the results involving $\mathrm{DCA}_{0}$ only for the firms for which I am able to calculate $\mathrm{DCA}_{-1}$ as well. By doing so, I ensure that the previous results are not biased by the better data availability of a certain type of firms (Note 12).

Table 5 shows the descriptive statistics of $\mathrm{DCA}_{0}$ for each country and the results of several tests for whether the mean (median) $\mathrm{DCA}_{0}$ is different from 0 . Similarly to the results of $\mathrm{DCA}_{0}$ in Table 1 , Table 5 shows that the average $\mathrm{DCA}_{0}$ is significantly positive in 14 out of 28 countries, and it is never significantly negative. Similarly, the results of the Wilcoxon's signed rank test show that the median $\mathrm{DCA}_{0}$ is significantly positive in 16 out of 28 countries. These results are in contrast with the results of $\mathrm{DCA}_{-1}$ in Table 1 which show that a vast majority of countries have a mean (median) $\mathrm{DCA}_{-1}$ that is not different from 0 . Table 5 results confirm that $\mathrm{DCA}_{0}$ is a biased measure of earnings management even when the sample size is restricted to only firms for which we are able to calculate $\mathrm{DCA}_{-1}$.

Table 6 shows the performance measure of IPO firms by DCA $_{0}$ quartile. Consistent with the results of Table 2, and with the results of TWW, firms that manage earnings more aggressively (Quartile 4) underperform the firms that have the lowest degree of earnings management (Quartile 1).

Table 7 shows the results of the multiple regression models used to explain the long-term performance of IPO firms. Similar to the results of Table 4, Table 7 shows that the coefficient of $\mathrm{DCA}_{0}$ is always negative and it is significant in 6 out of 8 models. The coefficients of the other variables in Table 7 are very similar to the coefficients of the variables in Table 3 and Table 4: Firms with higher growth opportunities (SalesGrowth), firms higher profitability (ROAGrowth), and ADR-IPOs (ADR) significantly outperform the other firms, while larger firms (LogAssets) and firms backed by a venture capitalist (VC) significantly underperform the other firms. The coefficients of UWRank and Lockup continue to remain insignificant in all models. 
Table 5. DCA description (robustness check)

\begin{tabular}{|c|c|c|c|c|c|c|}
\hline & Mean & Median & $\begin{array}{l}\text { Standard } \\
\text { Deviation }\end{array}$ & $\begin{array}{l}\text { Number } \\
\text { of Firms }\end{array}$ & $\begin{array}{l}\text { T-stat (T-Test } \\
\text { for the Mean) }\end{array}$ & $\begin{array}{l}\text { Z-stat (Wilcoxon's } \\
\text { Signed Rank Test) }\end{array}$ \\
\hline Country & $\mathbf{D C A}_{0}$ & $\mathbf{D C A}_{0}$ & $\mathbf{D C A}_{0}$ & $\mathbf{D C A}_{0}$ & $\mathbf{D C A}_{0}$ & $\mathbf{D C A}_{0}$ \\
\hline Australia & 0.065 & 0.011 & 0.364 & 237 & $2.699 * * *$ & $1.683 * *$ \\
\hline Austria & -0.013 & -0.044 & 0.104 & 4 & -0.254 & -0.365 \\
\hline Belgium & 0.000 & 0.000 & 0.319 & 14 & 0.004 & -0.031 \\
\hline Brazil & 0.156 & 0.060 & 0.381 & 24 & $1.967 *$ & $1.522 *$ \\
\hline Switzerland & -0.047 & -0.011 & 0.106 & 9 & -1.246 & -1.400 \\
\hline China & 0.097 & 0.076 & 0.219 & 904 & $13.266^{* * *}$ & $13.531 * * *$ \\
\hline Germany & 0.096 & 0.058 & 0.348 & 100 & $2.771 * * *$ & $2.617 * * *$ \\
\hline Denmark & 0.029 & 0.045 & 0.281 & 15 & 0.399 & 0.398 \\
\hline Spain & 0.159 & 0.120 & 0.309 & 7 & 1.362 & 1.189 \\
\hline Finland & -0.085 & -0.025 & 0.237 & 6 & -0.878 & -0.943 \\
\hline France & 0.056 & 0.037 & 0.286 & 110 & $2.011 * *$ & $1.806^{* *}$ \\
\hline Great Britain & 0.049 & 0.013 & 0.361 & 278 & $2.204 * *$ & $1.587 *$ \\
\hline Greece & 0.315 & 0.104 & 0.389 & 3 & 1.402 & $1.603 *$ \\
\hline Hong-Kong & 0.118 & 0.078 & 0.271 & 54 & $3.178 * * *$ & $3.085 * * *$ \\
\hline India & 0.117 & 0.098 & 0.306 & 233 & $5.784 * * *$ & $5.753 * * *$ \\
\hline Ireland & -0.088 & 0.019 & 0.227 & 6 & -0.952 & -0.314 \\
\hline Italy & 0.058 & 0.045 & 0.161 & 39 & $2.262 * *$ & $2.009 * *$ \\
\hline Japan & 0.023 & 0.010 & 0.137 & 468 & $3.686 * * *$ & $3.950 * * *$ \\
\hline South Korea & 0.099 & 0.060 & 0.165 & 7 & 1.594 & $1.521 *$ \\
\hline Mexico & 0.028 & 0.009 & 0.096 & 11 & 0.969 & 0.800 \\
\hline Malysia & 0.107 & 0.090 & 0.263 & 33 & $2.295^{* *}$ & $2.337 * * *$ \\
\hline Holland & -0.009 & -0.054 & 0.342 & 14 & -0.099 & -0.408 \\
\hline Norway & 0.018 & -0.055 & 0.288 & 22 & 0.296 & -0.828 \\
\hline New Zealand & 0.017 & -0.009 & 0.110 & 9 & 0.456 & 0.415 \\
\hline Singapore & 0.089 & 0.061 & 0.309 & 116 & $3.089 * * *$ & $3.343 * * *$ \\
\hline Sweden & 0.046 & 0.041 & 0.318 & 20 & 0.647 & 0.859 \\
\hline Thailand & 0.098 & 0.055 & 0.156 & 21 & $2.863 * * *$ & $2.693 * * *$ \\
\hline Taiwan & 0.046 & 0.033 & 0.157 & 200 & $4.097 * * *$ & $4.353 * * *$ \\
\hline
\end{tabular}

This table summarizes $\mathrm{DCA}_{0}$ by country and only includes the firms for which we are able to calculate $\mathrm{DCA}_{-1}$ as well. The left four columns provide the descriptive statistics, while the right two columns provide the test statistics that test whether the $\mathrm{DCA}_{0}$ for each country are statistically different from 0 (mean or median). *, **, and *** represent the level of significance at 10,5 , and $1 \%$, respectively.

Table 6. Median long-term abnormal returns by $\mathrm{DCA}_{0}$ quartiles (robustness check)

\begin{tabular}{ccccccccc}
\hline DCA $_{\mathbf{0}}$ Quartile & CAR3 & CAR5 & BHAR3 & BHAR5 & Alpha3 & Alpha5 & GAlpha3 & GAlpha5 \\
\hline 1 (Lowest) & 0.017457 & 0.134628 & -0.21844 & -0.29784 & 0.002176 & 0.006378 & 0.000103 & 0.005504 \\
2 & 0.0184 & 0.2243 & -0.1923 & -0.1800 & 0.0028 & 0.0081 & 0.0041 & 0.0063 \\
3 & -0.0004 & 0.1961 & -0.2518 & -0.3118 & 0.0026 & 0.0049 & 0.0036 & 0.0039 \\
4 (Highest) & -0.0294 & 0.0978 & -0.2845 & -0.3703 & 0.0020 & 0.0044 & -0.0003 & 0.0024 \\
\hline Total & 0.0005 & 0.1544 & -0.2408 & -0.2925 & 0.0024 & 0.0063 & 0.0022 & 0.0045 \\
\hline
\end{tabular}


This table reports the median abnormal return across several measures and several time horizons for each DCA $_{0}$ quartile. The results are shown only the firms for which we are able to calculate $\mathrm{DCA}_{-1}$ as well. The $\mathrm{DCA}_{0}$ quartiles are calculated for each country separately. Each column represents a different measure of long term abnormal return (CAR, BHAR, Alpha, or GAlpha) in the 3 and 5 year period following the IPO (the period longevity is indicated by the number that follows each abnormal return measure).

\section{Conclusion}

This study tests and finds support for two opposing hypotheses regarding earnings management by IPO firms. Consistent with the hypothesis of BS that IPO firms report higher quality earnings and are unlikely to engage in earnings management, I find that, on average, IPO firms have pre-IPO DCA that are not significantly different from 0 . However, DCA from virtually all countries in the sample have very large variance, which may indicate that although, on average, IPO firms do not manage earnings, some firms do indeed report large earnings prior to the IPO. Also, consistent with BS' criticism of TWW, I find that the use of $\mathrm{DCA}_{0}$ exaggerates the degree of pre-IPO earnings management. When $\mathrm{DCA}_{0}$ is used as a proxy for pre-IPO earnings management, about half of the countries in the sample appear to have significantly positive accruals (pre-IPO earnings management). This result is not observed when the true measure of pre-IPO earnings management $\left(\mathrm{DCA}_{-1}\right)$ is used. $\mathrm{DCA}_{-1}$ are insignificantly different from 0 in most countries. Further, the mean (median) $\mathrm{DCA}_{0}$ is significantly greater than the mean (median) $\mathrm{DCA}_{-1}$ in 10 (12) out of 28 countries

This paper also explores the effect of earnings management on IPO firm long-term underperformance and finds a significantly negative relationship. This negative relationship is persistent over different measures of long-term stock performance (CAR, BHAR, of Fama and French 4-factor model), over different time horizons ( 3 and 5 years), over several measures of earnings management $\left(\mathrm{DCA}_{-1}\right.$ or $\left.\mathrm{DCA}_{0}\right)$, and holds even after controlling for firm-specific variables that help explain long-term performance and country fixed effects. This result is consistent with the hypothesis of TWW that IPO firms that engage in earnings management underperform over the long run. Overall, these results suggest that, on average, IPO firms do not engage in pre-IPO earnings management; however, the ones that do underperform over the long run.

Table 7. Cross-sectional regression for abnormal performance using $\mathrm{DCA}_{0}$ (robustness check)

\begin{tabular}{|c|c|c|c|c|c|c|c|c|}
\hline \multirow[b]{3}{*}{$\begin{array}{l}\text { Independent } \\
\text { Variables }\end{array}$} & \multicolumn{8}{|c|}{ Dependent Variable } \\
\hline & CAR3 & CAR5 & BHAR3 & BHAR5 & Alpha3 & Alpha5 & GAlpha3 & GAlpha5 \\
\hline & & & & & & & & \\
\hline Constant & $\begin{array}{c}0.180 * * * \\
(2.65)\end{array}$ & $\begin{array}{c}0.513^{* * *} \\
(5.89)\end{array}$ & $\begin{array}{l}0.258^{* *} \\
(2.20)\end{array}$ & $\begin{array}{c}0.549 * * * \\
(2.80)\end{array}$ & $\begin{array}{c}0.00965 * * * \\
(3.81)\end{array}$ & $\begin{array}{c}0.0141^{* * *} \\
(7.66)\end{array}$ & $\begin{array}{c}0.0100^{* * *} \\
(4.00)\end{array}$ & $\begin{array}{c}0.0109 * * * \\
(6.13)\end{array}$ \\
\hline $\mathrm{DCA}_{0}$ & $\begin{array}{c}-0.0714 \\
(-0.96)\end{array}$ & $\begin{array}{c}-0.242 * * \\
(-2.56)\end{array}$ & $\begin{array}{l}-0.188 \\
(-1.46)\end{array}$ & $\begin{array}{c}-0.373^{*} \\
(-1.76)\end{array}$ & $\begin{array}{c}-0.00558 * * \\
(-2.00)\end{array}$ & $\begin{array}{c}-0.00807^{* * * *} \\
(-4.05)\end{array}$ & $\begin{array}{c}-0.00619 * * \\
(-2.25)\end{array}$ & $\begin{array}{c}-0.00863 * * * \\
(-4.46)\end{array}$ \\
\hline SalesGrowth & $\begin{array}{c}0.00770^{* * *} \\
(\mathbf{3 . 0 2})\end{array}$ & $\begin{array}{c}0.00431 \\
(1.37)\end{array}$ & $\begin{array}{c}0.0187 * * * \\
(4.26)\end{array}$ & $\begin{array}{c}0.00808 \\
(1.14)\end{array}$ & $\begin{array}{c}0.000208 * * \\
(2.20)\end{array}$ & $\begin{array}{c}0.000121 * \\
(1.84)\end{array}$ & $\begin{array}{c}0.000165^{*} \\
(1.76)\end{array}$ & $\begin{array}{c}0.00009 \\
(1.47)\end{array}$ \\
\hline ROAGrowth & $\begin{array}{c}0.0928^{* * *} \\
(4.16)\end{array}$ & $\begin{array}{c}0.107^{* * *} \\
(3.89)\end{array}$ & $\begin{array}{c}0.0645^{*} \\
(1.67)\end{array}$ & $\begin{array}{c}0.106^{*} \\
(1.71)\end{array}$ & $\begin{array}{c}0.00334 * * * \\
(4.05)\end{array}$ & $\begin{array}{c}0.00224 * * * \\
(3.89)\end{array}$ & $\begin{array}{c}0.00283^{* * *} \\
(3.45)\end{array}$ & $\begin{array}{c}0.00202 * * * \\
(3.59)\end{array}$ \\
\hline UWRank & $\begin{array}{c}0.00836 \\
(0.66)\end{array}$ & $\begin{array}{c}0.00515 \\
(0.32)\end{array}$ & $\begin{array}{c}0.0208 \\
(0.95)\end{array}$ & $\begin{array}{c}0.00399 \\
(0.11)\end{array}$ & $\begin{array}{c}0.00044 \\
(0.92)\end{array}$ & $\begin{array}{c}0.0000283 \\
(0.08)\end{array}$ & $\begin{array}{c}-0.0000852 \\
(-0.18)\end{array}$ & $\begin{array}{c}0.0000713 \\
(0.22)\end{array}$ \\
\hline LogAssets & $\begin{array}{l}-0.0247 \\
(-1.64)\end{array}$ & $\begin{array}{c}-0.0683 * * * \\
(-3.54)\end{array}$ & $\begin{array}{l}-0.0401 \\
(-1.54)\end{array}$ & $\begin{array}{c}-0.0855^{* *} \\
(-1.97)\end{array}$ & $\begin{array}{c}-0.000875 \\
(-1.56)\end{array}$ & $\begin{array}{c}-0.00128 * * * \\
(-3.12)\end{array}$ & $\begin{array}{c}-0.00109 * * \\
(-1.97)\end{array}$ & $\begin{array}{c}-0.00107 * * * \\
(-2.70)\end{array}$ \\
\hline Lockup & $\begin{array}{l}0.025 \\
(0.32)\end{array}$ & $\begin{array}{c}0.0148 \\
(0.15)\end{array}$ & $\begin{array}{l}-0.204 \\
(-1.52)\end{array}$ & $\begin{array}{l}-0.278 \\
(-1.23)\end{array}$ & $\begin{array}{c}0.00156 \\
(0.54)\end{array}$ & $\begin{array}{c}-0.00212 \\
(-1.00)\end{array}$ & $\begin{array}{c}0.000708 \\
(0.25)\end{array}$ & $\begin{array}{l}-0.0011 \\
(-0.53)\end{array}$ \\
\hline $\mathrm{VC}$ & $\begin{array}{c}-0.224 * * * \\
(-3.36)\end{array}$ & $\begin{array}{c}-0.207 * * \\
(-2.44)\end{array}$ & $\begin{array}{c}-0.232 * * \\
(-2.02)\end{array}$ & $\begin{array}{l}-0.153 \\
(-0.80)\end{array}$ & $\begin{array}{c}-0.0122 * * * \\
(-4.92)\end{array}$ & $\begin{array}{c}-0.00782 * * * \\
(-4.39)\end{array}$ & $\begin{array}{c}-0.00931 * * * \\
(-3.79)\end{array}$ & $\begin{array}{c}-0.00498 * * * \\
(-2.86)\end{array}$ \\
\hline $\mathrm{ADR}$ & $\begin{array}{l}0.203 * * \\
(2.27)\end{array}$ & $\begin{array}{c}0.236 * * \\
(2.05)\end{array}$ & $\begin{array}{c}0.272^{*} \\
(1.76)\end{array}$ & $\begin{array}{c}0.804 * * * \\
(3.11)\end{array}$ & $\begin{array}{c}0.00458 \\
(1.36)\end{array}$ & $\begin{array}{c}0.00654 * * * \\
(2.66)\end{array}$ & $\begin{array}{c}0.00479 \\
(1.46)\end{array}$ & $\begin{array}{c}0.00553 * * \\
(2.34)\end{array}$ \\
\hline $\begin{array}{l}\text { Country } \\
\text { Fixed Effects }\end{array}$ & Yes & Yes & Yes & Yes & Yes & Yes & Yes & Yes \\
\hline $\begin{array}{l}\mathrm{N} \\
\mathrm{R}-\mathrm{sq}\end{array}$ & $\begin{array}{l}2431 \\
0.020\end{array}$ & $\begin{array}{l}2406 \\
0.020\end{array}$ & $\begin{array}{l}2297 \\
0.016\end{array}$ & $\begin{array}{l}2274 \\
0.010\end{array}$ & $\begin{array}{l}2431 \\
0.023\end{array}$ & $\begin{array}{l}2431 \\
0.032 \\
\end{array}$ & $\begin{array}{l}2297 \\
0.017\end{array}$ & $\begin{array}{l}2297 \\
0.025\end{array}$ \\
\hline
\end{tabular}


This table shows the results of the cross-sectional regressions used to explain the long-term performance of IPO firms. In each model, the dependent variable is a measure of long-term abnormal return (CAR, BHAR, Alpha, or GAlpha) in the 3 and 5 year period following the IPO (the period longevity is indicated by the number that follows each abnormal return measure). The t-statistics are shown in brackets. *,**, and ${ }^{* * *}$ represent the level of significance at 10,5 , and $1 \%$, respectively.

\section{References}

Alti, A. (2006). How Persistent is the Impact of Market Timing on Capital Structure? The Journal of Finance, 61(4), 1681-1710. http://dx.doi.org/10.1111/j.1540-6261.2006.00886.x

Ball, R., \& L. Shivakumar. (2008). Earnings Quality at Initial Public Offerings. Journal of Accounting \& Economics, 45(2), 324-349. http://dx.doi.org/10.1016/j.jacceco.2007.12.001

Brau, J. C., \& S.E. Fawcett. (2006). Evidence on What CFOs Think About the IPO Process: Practice, Theory, and Managerial Implications. Journal of Applied Corporate Finance, 18(3), 107-117. http://dx.doi.org/10.1111/j.1745-6622.2006.00103.x

Carter, R., \& S. Manaster. (1990). Initial Public Offerings and Underwriter Reputation. Journal of Finance, 45, 1045-1067.

Chemmanur, T. J., \& J. He. (2011). IPO Waves, Product Market Competition, and the Going Public Decision: Theory and Evidence. Journal of Financial Economics, 101(2), 382-412. http://dx.doi.org/10.1016/j.jfineco.2011.03.009

DuCharme, L., P.H. Malatesta, \& S.E. Sefcik. (2001). Earnings Management: IPO Valuation and Subsequent Performance. Journal of Accounting, Auditing \& Finance, 16(4), 369-396.

Givoly, D., C.K. Hayn, \& S.P. Katz. (2010). Does Public Ownership of Equity Improve Earnings Quality? The Accounting Review, 85(1), 195-225. http://dx.doi.org/10.2308/accr.2010.85.1.195

Graham, J. R., C.R. Harvey, \& S. Rajgopal. (2005). The Economic Implications of Corporate Financial Reporting. Journal of Accounting \& Economics, 40(1-3), 3-73. http://dx.doi.org/10.1016/j.jacceco.2005.01.002

Ibbotson, R. (1975). Price Performance of Common Stock New Issues. Journal of Financial Economics, 2(3), 235-272. http://dx.doi.org/10.1016/0304-405X(75)90015-X

Jegadeesh, N., M. Weinstein, \& I. Welch. (1993). An Empirical Investigation of IPO Returns and Subsequent Equity Offerings. Journal of Financial Economics, 34(2), 153-175. http://dx.doi.org/10.1016/0304-405X(93)90016-5

Lee, H. W., Y. A. Xie, \& J. Zhou. (2012). Role of Underwriters in Restraining Earnings Management in Initial Public Offerings. Journal of Applied Business Research, 28(4), 709-723.

Levis, M. (1993). The Long-Run Performance of Initial Public Offerings: The UK Experience 1980-88. Financial Management, 22, 28-41. http://dx.doi.org/10.2307/3665963

Lubberink, M. J. P., \& C. Huijgen. (2006). Earnings Conservatism and Equity Raisings of Cross-Listed Firms. Working Paper.

Ritter, J.R. (1991). The Long-Run Performance of Initial Public Offerings. The Journal of Finance, 46(1), 3-27. http://dx.doi.org/10.1111/j.1540-6261.1991.tb03743.x

Roosenboom, P., T. van der Goot, \& G. Mertens. (2003). Earnings Management and Initial Public Offerings: Evidence from the Netherlands. The International Journal of Accounting, 38(3), 243-266. http://dx.doi.org/10.1016/S0020-7063(03)00048-7

Schaub, M. (2011). Does Market Timing or Issue Type Affect the Long-Run Performance of UK American Depository Receipts Listed on the New York Stock Exchange? Journal of Asset Management, 12(3), 157-162. http://dx.doi.org/10.1057/jam.2011.8

Schultz, P. (2003). Pseudo Market Timing and the Long-Run Underperformance of IPOs. The Journal of Finance, 58(2), 483-517. http://dx.doi.org/10.1111/1540-6261.00535

Seger, J. (2009). Cooking the Books around Initial Public Offerings. Erasmus University Rotterdam, 26-46.

Teoh, S. H., I. Welch, \& T. J. Wong. (1998). Earnings Management and the Long--Run Market Performance of Initial Public Offerings. Journal of Finance, 53(6), 1935-1974. http://dx.doi.org/10.1111/0022-1082.00079 
White, H. (1980). A Heteroskedasticity-Consistent Covariance Matrix Estimator and a Direct Test for Heteroskedasticity. Econometrica, 48(4), 817-817. http://dx.doi.org/10.2307/1912934

Xiong, Y., H. Zhou, \& S. Varshney. (2010). The Economic Profitability of pre-IPO Earnings Management and IPO Underperformance. Journal of Economics and Finance, 34(3), 229-256. http://dx.doi.org/10.1007/s12197-008-9056-0

\section{Notes}

Note 1. DCA $\mathrm{A}_{0}$ reflects the earnings in the IPO year. These earnings are reported after the IPO date and are unlikely to affect the IPO pricing. The earnings that IPO investors see at the IPO date are the pre-IPO earnings.

Note 2. Although the focus of this paper is on the pre-IPO abnormal accruals, as a robustness test I discuss the results by using $\mathrm{DCA}_{0}$ as a proxy for earnings management.

Note 3. See Ibbotson (1975), Ritter (1991), Jegadeesh et al. (1993), Levis (1993), and Schultz (2003).

Note 4. Prior to 1988, the data needed to calculate DCA are not available in Compustat Global.

Note 5.43 of these countries had fewer than 10 IPOs during this period.

Note 6. http://mba.tuck.dartmouth.edu/pages/faculty/ken.french/data_library.html\#International

Note 7. To minimize the effect of outliers, DCA are winsorized at the $1 \%$ level.

Note 8. Due to the large size of Table 1, the results of the t-test and the Wilcoxon's test conducted in each country and test whether $\mathrm{DCA}_{0}$ is greater than $\mathrm{DCA}_{-1}$ are not reported in Table 1, however, they are available upon request.

Note 9. A popular proxy for firm's growth opportunities is also Market to Book ratio (MTB) or Tobin's Q. However given our hypothesis that earnings management affects IPO price, if there is such a relation, a higher IPO price would result in a higher MTB or higher Tobin's Q. If these variables were to be included in the model, they would at least partially capture the effect of DCA on long term performance, thus resulting in a biased coefficient for DCA.

Note 10. http://bear.warrington.ufl.edu/ritter/ipodata.htm

Note 11. Lower quality firms would have no incentive to expose themselves to higher scrutiny and regulation.

Note 12. E.g. larger firms could have better data availability, and therefore the results involving DCA $_{-1}$ could be biased towards larger firms. Measuring $\mathrm{DCA}_{0}$ only for the firms for which data availability allows the calculation of DCA $_{-1}$ as well, removes this sample selection bias, and ensures the comparability of results. This sample selection bias is not removed in the main results in order to preserve the comparability of the results with the results of TWW. TWW do not adjust for such sample selection bias. 